\title{
Determination of Five Heavy Metals in White Yam (Dioscorea Rotundata) and Three- Leaved Yam (Dioscorea Dumetorum) from Farms in Khana, Rivers State
}

\author{
Ihesinachi A. Kalagbor ${ }^{1}$, Dumbari L. Adooh ${ }^{1} \&$ Rebecca James ${ }^{1}$ \\ ${ }^{1}$ Department of Science Laboratory Technology, School of Applied Sciences, Rivers State Polytechnic, Bori, \\ Nigeria \\ Correspondence: Ihesinachi A. Kalagbor, Department of Science Laboratory Technology, School of Applied \\ Sciences, Rivers State Polytechnic, Bori, Nigeria. Tel: 234-803-309-8983. E-mail: ksinachi@yahoo.com
}

Received: July 24, 2015 Accepted: August 12, 2015 Online Published: September 28, 2015

doi:10.5539/ep.v4n4p18 URL: http://dx.doi.org/10.5539/ep.v4n4p18

\begin{abstract}
Background: The Niger Delta Region has experienced various levels of pollutions from industries and oil exploration. Studies have revealed that the ongoing pollution is affecting the quality of agriculture produce from this region. Rivers State is one of the states in the Niger Delta and its farmlands have been affected by oil exploration. This study is aimed at determining the levels of five heavy metals $(\mathrm{Cu}, \mathrm{Fe}, \mathrm{Ni}, \mathrm{Pb}$ and $\mathrm{Zn})$ in white yam (dioscorea rotundata) and three-leaved yam (Dioscora dumentorum) using AAS.

Research Methodology: The samples used for this study were harvested from farms in Zaakpon and Kaani in Khana Local Government area of Rivers State, Nigeria.

Results: Concentration of $\mathrm{Cu}$ in white yam $(11.86 \mathrm{mg} / \mathrm{kg})$ and three-leaved yam $(8.90 \mathrm{mg} / \mathrm{kg})$ harvested from Zaakpon were found to be higher than those from Kaani, whereas Fe concentration in white yam $(43.20 \mathrm{mg} / \mathrm{kg})$ and three-leaved yam $(144.0 \mathrm{mg} / \mathrm{kg}$ ) from Kaani were higher than those from Zaakpon. Ni and $\mathrm{Pb}$ concentration were also higher in the samples from Zaakpon while $\mathrm{Zn}$ concentrations in the samples from the two farmlands were below acceptable limits. The dietary intake rate (DIR) values $\left(\mathrm{mg}\right.$ person $^{-1}$ day $\left.^{-1}\right)$ were calculated using Parkhurst equation and the following was obtained for $\mathrm{Cu}(0.044-0.124), \mathrm{Fe}(0.229-1.510)$, Ni $(0.0214$ $0.138), \mathrm{Pb}(0.001-0.141)$ and $\mathrm{Zn}(0.022-0.145)$.

Conclusion: From the results obtained, it follows that the continued consumption of these crops harvested from the farms will have adverse effects on the consumers. This calls for close monitoring of the farmlands for heavy metal contamination.
\end{abstract}

Keywords: agricultural sites, dietary intake rate (DIR), environmental contaminants, farmlands, Kaani, three-leaved yam, white yam, Zaakpon

\section{Introduction}

The white yam (Dioscorea rotundata) is native of Africa. It is one of the most cultivated yams. There are over 200 cultivated varieties of it. Three-leaved yam (Dioscorea dumetorum) is popular in parts of West Africa because their cultivation requires less labor than the other yams. It is also known as bitter yam or cluster yam and comes in four varieties of yellow and white. The yellow variety is the most preferred of the two edible varieties. The other two varieties are toxic. The yellowish-white is toxic to animal alone and the white variety is toxic to both animal and man (Ojo \& Ojo, 2009). The toxic varieties are not edible but they are commonly used for pharmaceutical or medicinal purposes by African or Asian people ( Mc Anuff, Harding, Omorunyi, Jacobs, Morrison \&Asemota, 2003). White yam and three-leaved yam form edible tubers. They are perennial herbaceous vines cultivated for the consumption of their starchy tubers commonly in Africa, Asia, Latin America, etc.

The mode of cultivation is by seedlings, which matures after about 9 months and are harvested. These tubers, as they grow and absorb nutrients from the soil also take up the heavy metals in the soil. Kaplan, Orman, Kadar \& Koncz, (2005) in their work showed that individual plants have different capacity to absorb and accumulate heavy metals which leads to contamination of the food chain. The consumption of heavy metal-contaminated food can seriously deplete some essential nutrients in the body causing a decrease in immunological defenses, 
intrauterine growth retardation, impaired psycho-social behaviors, disabilities associated with malnutrition and a high prevalence of upper gastrointestinal cancer (Arora, Kiran, Rani, Rani, Kaur \& Mittal, 2008). Orisakwe, Nduka, Amadi, Dike \& Bede (2012) demonstrated from their results, that the foods grown on contaminated soil are contaminated with heavy metals which pose a major health concern. Oti \& Nwabue (2013) reported high leads of the metals studied with $\mathrm{As}$ and $\mathrm{Pb}$ exceeding WHO maximum limits in Dioscorea rotundata (white yam), similarly As exceeded WHO maximum limits in Ipomoea batatas (Sweet Potato) and noted that the consumption of these tubers over a period of time may result to bioaccumulation of these toxic metals which can lead to adverse health effect or even death. Orisakwe et al, (2012) estimation of daily intake rate of $\mathrm{Pb}$ and $\mathrm{Cd}$ were above the tolerable daily intake rates for some of the food stuffs studied that are grown and sold in South eastern Nigeria. The degree of toxicity of heavy metals to human beings depends upon their intake. Agricultural sites in Khana Local Government Area of Rivers State are under threat of metal contamination as human activities increase. It has received elevated impacts of metals as a result of atmospheric deposition, automobile repairs, metal work and oil spoilage. The use of agricultural produce from farmlands in Zaakpon and Kaani has been of great importance to the people living within and outside these communities. These farmlands are thus vulnerable to environmental contaminants. These facts provide a solid foundation for which this study is carried out.

\section{Materials and Methods}

\subsection{Sample Collection}

Tubers of white yam and three-leaved yam were harvested from farmlands in Zaakpon and Kaani. These crops were properly washed, peeled and edible parts were chipped and air dried for about 5 weeks to reduce their water content, after which they were ground using mortar and pestle into flour respectively.

\subsection{Digestion of Samples}

About $1 \mathrm{~g}$ of each of the ground yam flour was weighed using analytical balance into four beakers and these were labeled properly. A solution of perchloric acid and nitric acid $(1: 4 \mathrm{v} / \mathrm{v})$ was prepared and $10 \mathrm{ml}$ of this oxi-acidic mixture was added to each of the contents of the beakers. The mixtures were stirred and allowed to stand for about $15 \mathrm{mins}$ and then heated for $4 \mathrm{hrs}$ to enhance complete digestion. The resulting solutions were then diluted with deionized water, stirred and filtered separately into four $50 \mathrm{ml}$ volumetric flasks. The filtrate was made up to mark with more deionized water and shaken to ensure homogeneity. The resultant sample solutions were then taken for heavy metal analysis using AAS.

\subsection{DIR Calculation}

Using the equation

$$
\mathrm{DIR}=\mathrm{C}_{\text {metal }} \times \mathrm{D}_{\text {food intake }} / \mathrm{B}_{\text {average weight }}
$$

Where

$\mathrm{C}_{\text {metal }}$ is heavy metal concentration in the tuber

$\mathrm{D}_{\text {food intake }}$ is daily intake of crop/tuber ( $\mathrm{kg} /$ person)

$\mathrm{B}_{\text {average weight }}$ is the average adult body weight

The average adult body weight according to Ge (1992) and Wang et al. (2005) is 55.9kg.

\section{Results and Discussion}

Table 1. Concentration of heavy metals $(\mathrm{mg} / \mathrm{kg})$

\begin{tabular}{lllllll}
\hline \multicolumn{5}{c}{ Zaakpon } & \multicolumn{2}{c}{ Kaani } \\
\hline & Metals & Three-leaved Yam & White yam & Three-leaved & White yam & FAO/WHO Acceptable Limits \\
\hline 1 & $\mathrm{Cu}$ & 8.90 & 11.86 & 4.24 & 4.84 & 0.5 \\
2 & $\mathrm{Fe}$ & 65.60 & 21.80 & 144.0 & 43.20 & 0.8 \\
3 & $\mathrm{Ni}$ & 2.04 & 13.28 & 4.17 & 4.00 & 0.14 \\
4 & $\mathrm{~Pb}$ & 0.10 & 13.44 & 0.74 & 2.42 & 0.10 \\
5 & $\mathrm{Zn}$ & 13.92 & 7.08 & 21.40 & 12.20 & 99.4 \\
\hline
\end{tabular}


Table 2. Daily intake rate (DIR), mg/person/year

\begin{tabular}{lllllll}
\hline \multicolumn{3}{c}{ Zaakpon } & \multicolumn{3}{c}{ Kaani } \\
\hline & Metals & Three-leaved Yam & White yam & Three-leaved & White yam & Average/STD \\
\hline 1 & $\mathrm{Cu}$ & 34.07 & 45.40 & 16.23 & 18.53 & $28.56 \pm 13.7$ \\
2 & $\mathrm{Fe}$ & 215.12 & 83.45 & 551.23 & 165.37 & $253.79 \pm 205.6$ \\
3 & $\mathrm{Ni}$ & 7.82 & 50.84 & 15.96 & 15.31 & $22.48 \pm 19.3$ \\
4 & $\mathrm{~Pb}$ & 0.38 & 51.45 & 2.83 & 9.26 & $15.98 \pm 23.9$ \\
5 & $\mathrm{Zn}$ & 53.29 & 27.10 & 81.92 & 46.70 & $52.25 \pm 22.7$ \\
\hline
\end{tabular}

Table 3. Daily intake rate (DIR), mg/person/day

\begin{tabular}{llrrrrr}
\hline & \multicolumn{2}{c}{ Zaakpon } & \multicolumn{3}{c}{ Kaani } \\
\hline & Metals & Three-leaved Yam & White yam & Three-leaved & White yam & Average \\
\hline 1 & $\mathrm{Cu}$ & 0.093 & 0.124 & 0.044 & 0.051 & 0.078 \\
2 & $\mathrm{Fe}$ & 0.589 & 0.229 & 1.510 & 0.453 & 0.695 \\
3 & $\mathrm{Ni}$ & 0.021 & 0.139 & 0.044 & 0.042 & 0.062 \\
4 & $\mathrm{~Pb}$ & 0.001 & 0.141 & 0.008 & 0.025 & 0.044 \\
5 & $\mathrm{Zn}$ & 0.146 & 0.074 & 0.224 & 0.128 & 0.143 \\
\hline
\end{tabular}

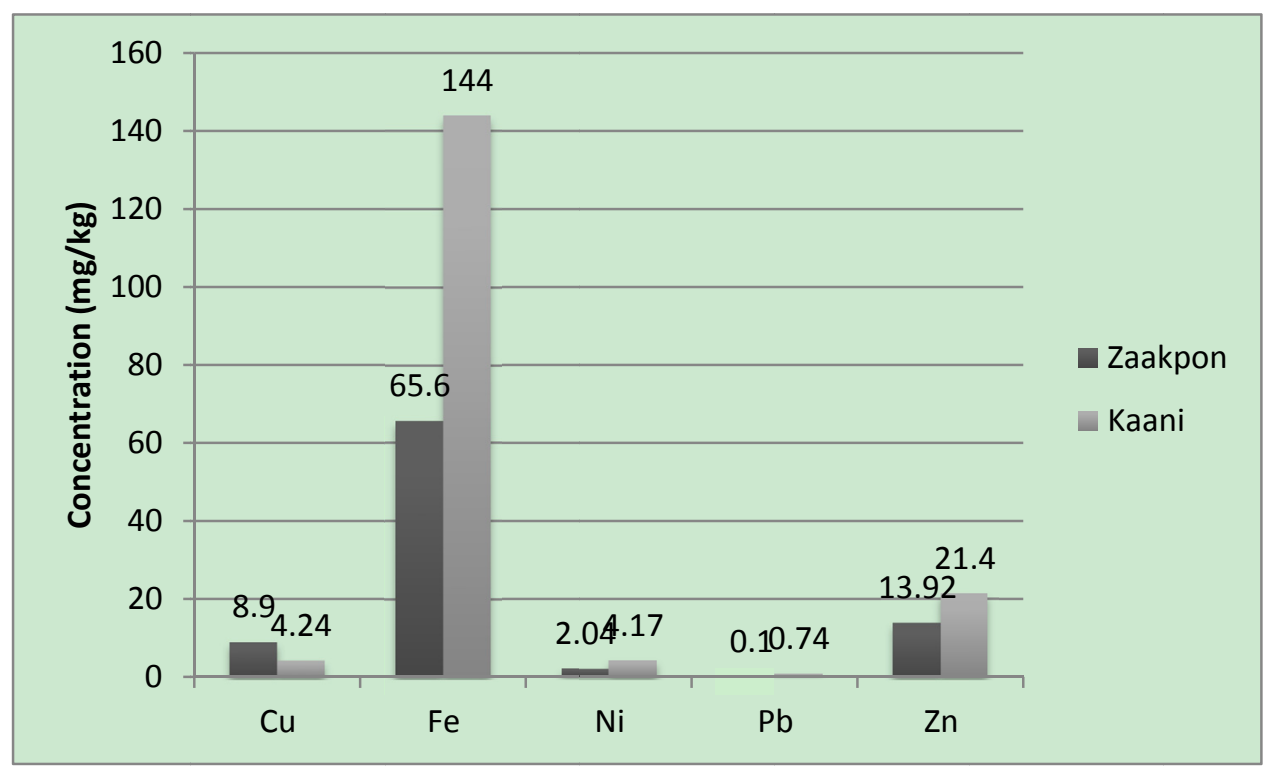

Figure 1. Concentration of the metals for Three-leaved yam 


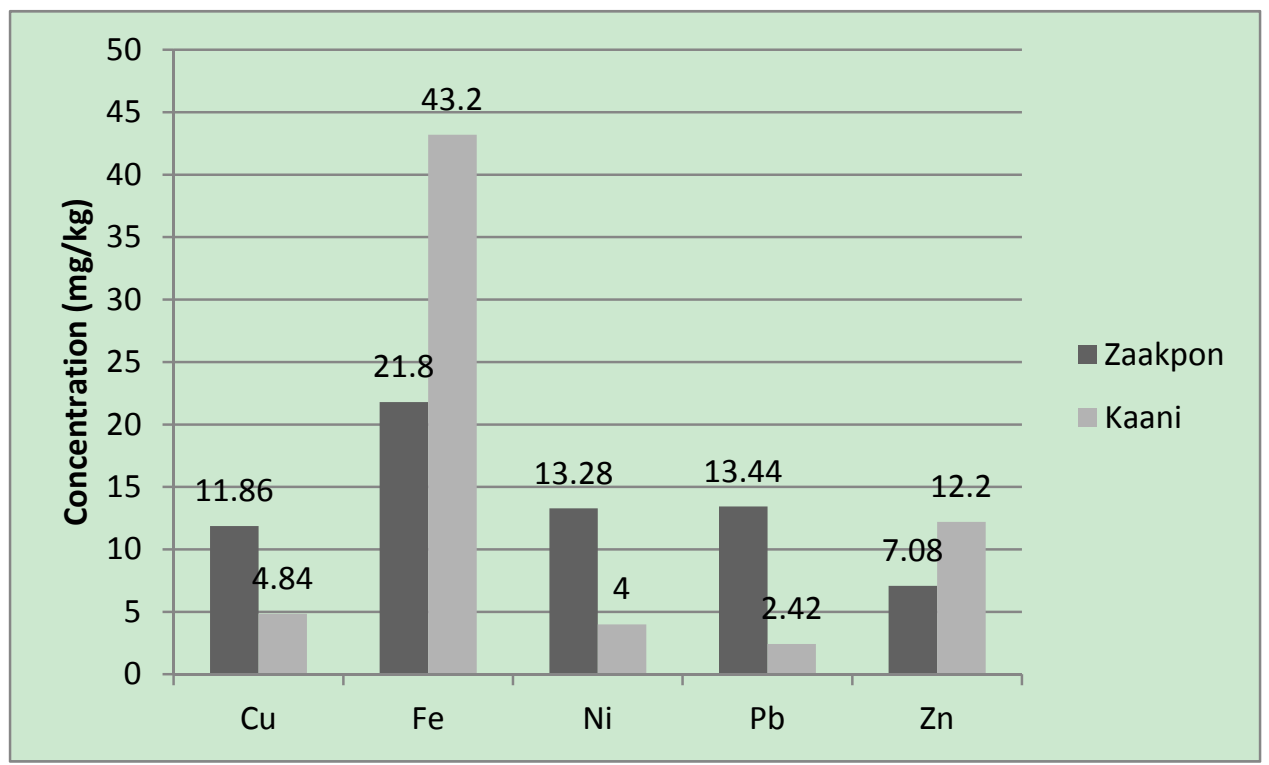

Figure 2. Concentration of the metals for white yam

\section{Discussion}

The concentrations of metals in the white yam and three-leaved yam are presented in Table 1 . The concentrations of $\mathrm{Cu}$ for three-leaved yam from Zaakpon were found to be twice as high $(8.90 \mathrm{mg} / \mathrm{kg})$ as that from Kaani $(4.24$ $\mathrm{mg} / \mathrm{kg})$. The white yam from Zaakpon also has two and half times more concentration $(11.86 \mathrm{mg} / \mathrm{kg})$ than the white yam harvested from Kaani as shown in Fig. 1.

However, Fe concentrations for both three-leaved yam and white yam from kaani $144.0 \mathrm{mg} / \mathrm{kg}$ and $43.20 \mathrm{mg} / \mathrm{kg}$ were about twice as high as those obtained for Zaakpon samples $(65.60 \mathrm{mg} / \mathrm{kg}$ and $21.80 \mathrm{mg} / \mathrm{kg})$ respectively. Report by Ojo and Ojo (2009) on the mineral composition of the two edible forms were $5.91 \mathrm{mg} / 100 \mathrm{~g}$ and 4 . $01 \mathrm{mg} / 100 \mathrm{~g}$ for the yellow and white varieties respectively for the stored (6 weeks) samples which is an equivalent of $59.1 \mathrm{mg} / \mathrm{kg}$ and $40.1 \mathrm{mg} / \mathrm{kg}$. The samples of the three-leaved yam used are the yellow varieties which were harvested during the previous year's harvest season.

From the above results, it therefore follows that the three-leaved yam and white yam have been exposed to high levels of Fe either from the soil or an immediate environmental pollution.

The concentrations of Ni were highest for the white yam $(13.28 \mathrm{mg} / \mathrm{kg})$ from Zaakpon, followed by the three-leaved yam $(4.17 \mathrm{mg} / \mathrm{kg})$ from Zaakpon and white yam $(4.00 \mathrm{mg} / \mathrm{kg})$ from Kaani. The high value recorded for white yam from Zaakpon is consistent with that reported by Oti and Nwabue, (2013).

White yam from Zaakpon farm has the highest concentration of $\mathrm{Pb}(13.44 \mathrm{mg} / \mathrm{kg})$ as shown in Fig. 2 while it has concentration of $0.10 \mathrm{mg} / \mathrm{kg}$ for the three-leaved yam. This level of $\mathrm{Pb}$ is too high and poses a serious health risk to consumers. Concentrations of $0.74 \mathrm{mg} / \mathrm{kg}$ and $2.42 \mathrm{mg} / \mathrm{kg}$ were recorded for three-leaved yam and white yam respectively for samples from Kaani.

The values for white yam are higher than those reported by Oti and Nwabue, (2013). Zn concentrations range from $7.08 \mathrm{mg} / \mathrm{kg}$ to $21.40 \mathrm{mg} / \mathrm{kg}$. Three leaved yam from Kaaani has the highest concentration $(21.80 \mathrm{mg} / \mathrm{kg})$ followed by the three-leaved yam from Zaakpon $(13.92 \mathrm{mg} / \mathrm{kg})$.

The white yams have values of $12.20 \mathrm{mg} / \mathrm{kg}$ (Kaani) and $7.08 \mathrm{mg} / \mathrm{kg}$ (Zaakpon). The values for $\mathrm{Zn}$ in all the samples are below the FAO and WHO acceptable limits of $99.40 \mathrm{mg} / \mathrm{kg}$ for crops. Miller and Miller (2000) noted that $\mathrm{Zn}$ and $\mathrm{Cu}$ are toxic to plants before they accumulate in sufficient (maximum) tissue concentrations to affect animals or humans. Their results showed that cassava plants are not hyper accumulators.

The estimated amount of heavy metals that can be in a person is obtained by calculating the dietary intake rate (DIR) using Parkhurst equation. The value used for the yearly intake of yam (which is a tuber) is as quoted in the special report on staple crop production and consumption by Inter-reseaux (2010). The consumption of grains and root crops/tubers amount to $150 \mathrm{~kg}$ and $214 \mathrm{~kg}$ respectively per person, per year (in 2007) and the result are presented in Table 2. 
Results in Table 3 show the DIR in mg person ${ }^{-1}$ day $^{-1}$. The highest DIR average was recorded for Fe $(0.695 \mathrm{mg}$ person $^{-1} \mathrm{day}^{-1}$ and the trend is presented as $\mathrm{Fe}>\mathrm{Zn}>\mathrm{Cu}>\mathrm{Ni}>\mathrm{Pb}$ while the crop that showed the highest concentration for most of the metals is the white yam from Zaakpon, followed by the white yam from Kaani, then the three-leaved yam from Zaakpon.

From the results presented by Orisakwe et al., (2012); the levels of $\mathrm{Pb}$ for the following tuberous crops; cocoyam, cassava and yam were $0.22 \mathrm{mg} / \mathrm{kg}, 0.33 \mathrm{mg} / \mathrm{kg}$ and Nd respectively. The levels of Ni were $0.58 \mathrm{mg} / \mathrm{kg}, 0.33 \mathrm{mg} / \mathrm{kg}$ and $1.04 \mathrm{mg} / \mathrm{kg}$ respectively. These values are much lower than those obtained from this study. However, the results obtained by Oti and Nwabue (2013) compares favorably with the values obtained for $\mathrm{Pb}, \mathrm{Zn}$, and $\mathrm{Ni}$ for white yam in this study

\section{Conclusion}

These values obtained in this study are higher than the FAO/WHO acceptable limits which therefore indicates that daily consumption of these tubers is likely to predispose the consumers to high level accumulations of these heavy metals. In Nigeria where our Staple foods are predominantly the crops and tubers, the people of this area who feed from these farms are exposed to these heavy metals. They may not present health problems now, but with continued consumption of these tubers over the years there will be some health challenges. The white yam and three-leaved yam samples from the farm in Kaani has higher concentrations for Fe and $\mathrm{Zn}$ while Zaakpon samples have higher concentrations for $\mathrm{Cu}, \mathrm{Ni}$ and $\mathrm{Pb}$. This therefore calls for further investigation on the concentration of these metals in these communities as $\mathrm{Ni}$ and $\mathrm{Pb}$ are classified as carcinogens. Long term exposure can lead to damage of the liver, kidney, central nervous system, cancer and even death. The high concentration of Fe in these samples is a source of concern. Studies involving soil samples need to be carried out to ascertain the index transfer and correlation matrix.

\section{References}

Arora, M., Kiran, B., Rani, A., Kaur, B., \& Mittal, N. (2008). Heavy metal accumulation in vegetables irrigated with water from different sources. Food Chem, 11, 811-815. http://dx.doi.org/10.1016/j.foodchem.2008.04.049

Ge, K. Y. (1992). The status of Nutrient and meal of Chinese in the: Beijing people's Hygiene Press 1990, 415-434.

Inter- resaux. (2010). Staple crop production and consumption: Nigeria on the way to food self-sufficiency. Grain de sel., 51, 10-12.

Kaplan, M., Orman, S., Kadar, I., \& Koncz, J. (2005). Heavy Metal Accumulation in Calcareous Soil and Sorghum Plants after Addition of Sulphur-Containing Waste as a Soil Amendment in Turkey. Agric. Ecosyst.Environ., III, 41-46. http://dx.doi.org/10.1016/j.agee.2005.04.023

Mc Anuff, M. A., Harding, W. W., Omoruyi, F. O., Jacobs, H., Morrison, E. Y., \& Asemota, H. N. (2003). Alterations in intestinal morphology of streptozotocin induced diabetic rats fed Jamaican bitter yam (Dioscorea polygonoides) steroidal sapogenin extract. Nutrition Research, 23, 1569-1577. http://dx.doi.org/10.1016/S0271-5317(03)00163-5

Miller, D. M., \& Miller, W. P. (2000). Land application of water in: Handbook of soil science. Summer M. E. (Ed.) CRC Books New York.

Ojo, O. I., \& Ojo, J. O. (2009). A comparative study of Effects of storage on Basic Nutritional composition of Two Major Edible Dioscorea Dumentorum varieties. Global J. Pure Appl. Sc., 15(3\&4), 353-355. http://dx.doi.org/10.4314/gjpas.v15i3-4.48553

Orisakwe, O. E., Nduka, J. K., Amadi, C. N., Dike, D. O., \& Bede, O. (2012). Heavy metals health risk assessment for population via consumption of food crops and fruits in Owerri, South Eastern, Nigeria. Chemistry Central Journal, 6, 77-83. http://dx.doi.org/10.1186/1752-153X-6-77

Oti Wilberforce, J. O., \& Nwabue, F. I. (2013). Heavy metals effect due to contamination of vegetables from Enyigba Lead Mine in Ebonyi State, Nigeria. Environ. Pollut., 2(1), 19-26.

Oti Wilberforce, J. O., \& Nwabue, F. I. (2013). Uptake of Heavy Metals by Dioscorea rotundata (White Yam) and Ipomoea batatas (Sweet Potato) from Enyigba Lead-Zinc Derelict. Environ. Pollut., 2(2), 79-84.

Wang, X., Sato, T., Xing, B., \& Tao, S. (2005). Health risks of heavy metals in the general public in Tiajin China Via consumption of vegetable and fish. Sci. Total Environ., 350, 28-37. http://dx.doi.org/10.1016/j.scitotenv.2004.09.044 


\section{Copyrights}

Copyright for this article is retained by the author(s), with first publication rights granted to the journal.

This is an open-access article distributed under the terms and conditions of the Creative Commons Attribution license (http://creativecommons.org/licenses/by/3.0/). 